\title{
Patronage at the Court of Burgundy around 1500: A Note on the Death of St Nicholas Window in the Royal Ontario Museum
}

\section{Ariane Isler-De Jongh}

Volume 29, numéro 1-2, 2004

URI : https://id.erudit.org/iderudit/1069679ar

DOI : https://doi.org/10.7202/1069679ar

Aller au sommaire du numéro

\section{Éditeur(s)}

UAAC-AAUC (University Art Association of Canada | Association d'art des universités du Canada)

\section{ISSN}

0315-9906 (imprimé)

1918-4778 (numérique)

Découvrir la revue

\section{Citer cette note}

Isler-De Jongh, A. (2004). Patronage at the Court of Burgundy around 1500: A Note on the Death of St Nicholas Window in the Royal Ontario Museum. RACAR : Revue d'art canadienne / Canadian Art Review, 29(1-2), 75-87.

https://doi.org/10.7202/1069679ar

\section{Résumé de l'article}

Un vitrail, conservé au Royal Ontario Museum et représentant la mort de saint Nicolas, fait partie d'une série, maintenant dispersée, qui ornait quatre baies du cloître de la chartreuse de Louvain et racontait la vie du saint.

Cet article se veut un exposé de l'état des recherches à ce jour, tenant compte du fait que les autres panneaux de la série seront étudiés par les groupes de recherche du Corpus Vitrearum en Grande-Bretagne et aux États-Unis. Nous nous concentrons donc sur la personalité du donateur, Nicolas Ruterius (1442-1509), évêque d'Arras et chancelier de l'Université de Louvain, en même temps que grand administrateur et chargé de missions diplomatiques au service de quatre générations des ducs de Bourgogne.

Sa carrière est donc centrée sur la cour de Bourgogne, principalement à Malines où résidaient Marguerite d'York et Marie de Bourgogne et où il participe à la vie intellectuelle et artistique. Preuve en sont les donations mentionnées dans son testament et en particulier, parmi les livres légués au Collège d'Arras, des manuscrits enluminés spécialement pour lui. Une premère étude de ces manuscrits nous permet de proposer une relation à établir entre les ateliers créant les vitraux et ceux qui produisent les enluminures, contribuant ainsi à élargir le domaine de recherche sur le vitrail.
Tous droits réservés @ UAAC-AAUC (University Art Association of Canada | Association d'art des universités du Canada), 2005
Ce document est protégé par la loi sur le droit d'auteur. L'utilisation des services d'Érudit (y compris la reproduction) est assujettie à sa politique d'utilisation que vous pouvez consulter en ligne.

https://apropos.erudit.org/fr/usagers/politique-dutilisation/ 


\section{Patronage at the Court of Burgundy around 1500: a Note on the Death of St Nicholas Window in the Royal Ontario Museum}

ARIANE ISLER-DE JONGH, UNIVERSITY OF VICTORIA

\begin{abstract}
Résumé
Un vitrail, conservé au Royal Ontario Museum et représentant la mort de saint Nicolas, fait partie d'un série, maintenant dispersée, qui ornait quatre baies du cloître de la chartreuse de Louvain et racontait la vie du saint.

Cet article se veut un exposé de l'état des recherches à ce jour, tenant compte du fait que les autres panneaux de la série seront étudiés par les groupes de recherche du Corpus Vitrearum en Grande-Bretagne et aux Etats-Unis. Nous nous concentrons donc sur la personalité du donateur, Nicolas Ruterius (1442-1509), évêque d'Arras et chancelier de l'Université de Louvain, en même temps que grand administrateur et chargé de missions
\end{abstract}

diplomatiques au service de quatre générations des ducs de Bourgogne.

Sa carrière est donc centrée sur la cour de Bourgogne, principalement à Malines où résidaient Marguerite d'York et Marie de Bourgogne et où il participe à la vie intellectuelle et artistique. Preuve en sont les donations mentionnées dans son testament et en particulier. parmi les livres légués au Collège d'Arras, des manuscrits enluminés spécialement pour lui. Une premère étude de ces manuscrits nous permet de proposer une relation à établir entre les ateliers créant les vitraux et ceux qui produisent les enluminures, contribuant ainsi à élargir le domaine de recherche sur le vitrail.
A Museum (ROM) in Toronto is a panel representing the scene of the Death of St Nicholas (fig. 1). ' The saintly Bishop of Myra, dressed in his ecclesiastical finery, is mourned by a throng of diminutive angels, and by two male figures at the foot of the bed, their hands clasped in prayer. One of these may be the donor of the panel, shown having been interrupted from his devotions, with an open book of hours beside him on a prayerstool. A coat of arms composed of three vine leaves, and the initials " $N$ R" carved on the side of the stool, identify him as Nicolas Ruterius (1442-1509), a prominent figure at the court of the Duke of Burgundy in the late fifteenth and early sixteenth centuries. ${ }^{2}$ The intention of this note is to explore the artistic patronage of Ruterius and to suggest the possibility of influences crossing from the media of manuscript illumination to stained glass.

As was first demonstrated by Paul V. Maes, the ROM panel belongs to a series of six stained glass panels, now widely dispersed, all depicting scenes from the life of St Nicholas, Ruterius's name saint, which are recorded as once having decorated the Charterhouse of Louvain. ${ }^{3}$ The series includes the Birth of St Nicholas in the Victoria and Albert Museum, London (fig. 2), in which the new-born infant demonstrates his precocious strength by standing unaided in his bath, ${ }^{4}$ and two panels in the Metropolitan Museum in New York depicting the Consecration of St Nicholas as Bishop of Myra (fig. 3) and the Miracle of the Grain, in which the saint, having persuaded the captain of a grain ship to surrender his cargo to help the starving city, miraculously refills the corn bags (fig. 4). ${ }^{5} \mathrm{~A}$ fourth panel, now in the Burrell collection in Glasgow, shows Nicholas intervening to prevent the execution of three military officers who had been falscly accused (fig. 5). ${ }^{6} \mathrm{~A}$ fifth panel, depicting the saint intervening to save three penniless maidens from prostitution by throwing bags containing money for their dowry through the window of their house, is now known only through photographs (fig. 6). While the full extent of the program cannot now be known, the ROM panel presumably concluded the cycle, and is the only one to depict the patron. All the panels are approximately 70 by $45 \mathrm{~cm}$, except for the last, which lacks the distich at the bottom, and thus is shorter.

Nicolas Ruterius, also mentioned as de Ruyter or Le Ruistre, was born in Luxembourg around $1442 ;^{7}$ his father was a German priest and his mother came from Burgos in Spain - perhaps a sign of the times! He was educated at Trier, graduating as a magister. In 1473 Ruterius was one of three clerks assigned to the Parliament convened by Duke Charles the Bold at Malines, but probably he had been earlier in the service of Duke Philip the Good (d. 1467), as mentioned by Erasmus in two of his letters to him. ${ }^{8}$ His administrative carcer seems to have developed principally in the following years. After the death of Charles in 1477, he became secretary to the Privy Council of the young duchess, Mary of Burgundy, and then, after her marriage to Maximilian of Austria, first secretary of the court of justice and keeper of the seals: "secretaire audiencier, maistre des requestes, signant en finances et controsleur d'icelles," as described in a contemporary document. ${ }^{9}$ Ruterius was to be entrusted with many diplomatic missions, and when Duke Philip the Fair, son of Mary of Burgundy and Maximilian of Austria, came to power in 1494, he would be one of the duke's closest councillors and one of the administrators left in charge of the duchy when Philip went abroad. ${ }^{10}$

Like many of his age, Ruterius combined a career in secular politics with another in the church, and the latter was equally as brilliant. In 1473 he is already described as "protonotaire 
Figure I. Death of Saint Nicholas (ca. 1501), formerly from the Louvain Charterhouse. Royal Ontario Museum, Toronto, 958.119.1.

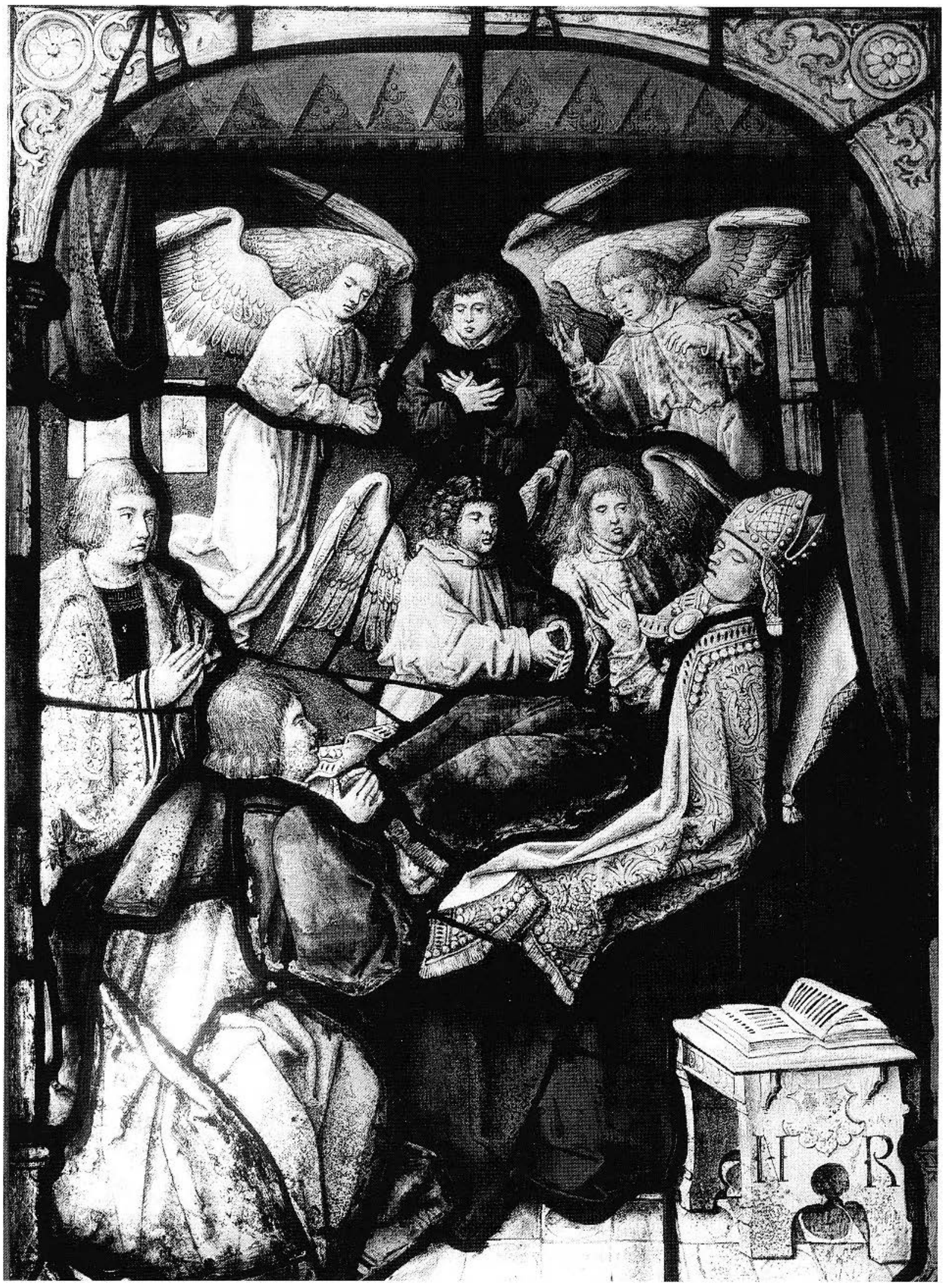


Figure 2. Birth of Saint Nicholas (early 16 th century), formerly from the Louvain Charterhouse. Victoria and Albert Museum, London, 213.1908.




Figure 3. Saint Nicholas consecrated Bishoo of Myra (early $16^{\text {th }}$ century), formerly from the Louvain Charterhouse. The Metropolitan Museum of Art, Mr and Mrs Isaac D. Fletcher collection, New York, 17.120.17.

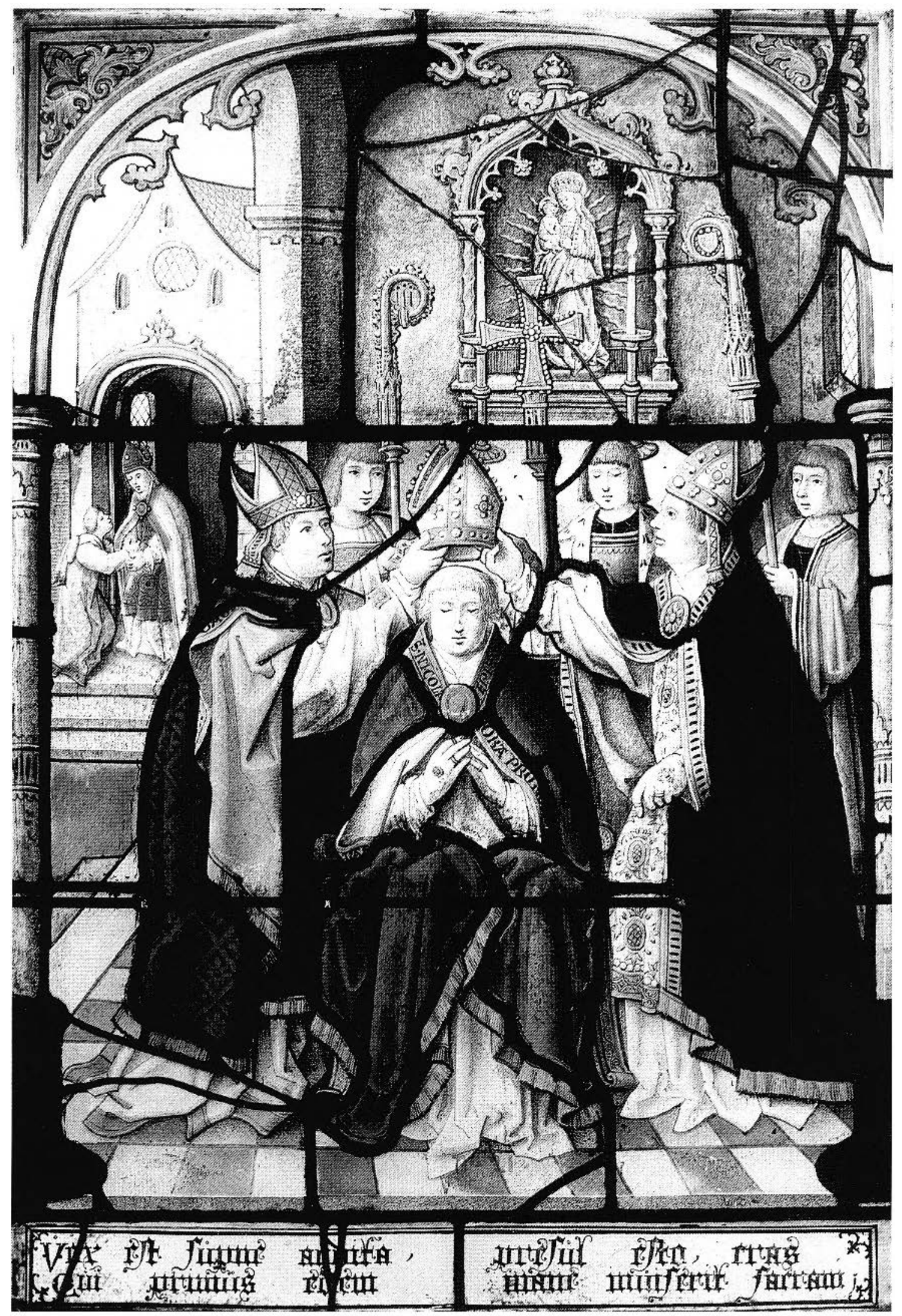


Figure 4. Saint Nicholas begging corn to feed his people (early $16^{\text {th }}$ century), formerly from the Louvain Charterhouse. Metropolitan Museum of Art, Mr and Mrs Isaac D. Fletcher collection, New York, 17.120.13.

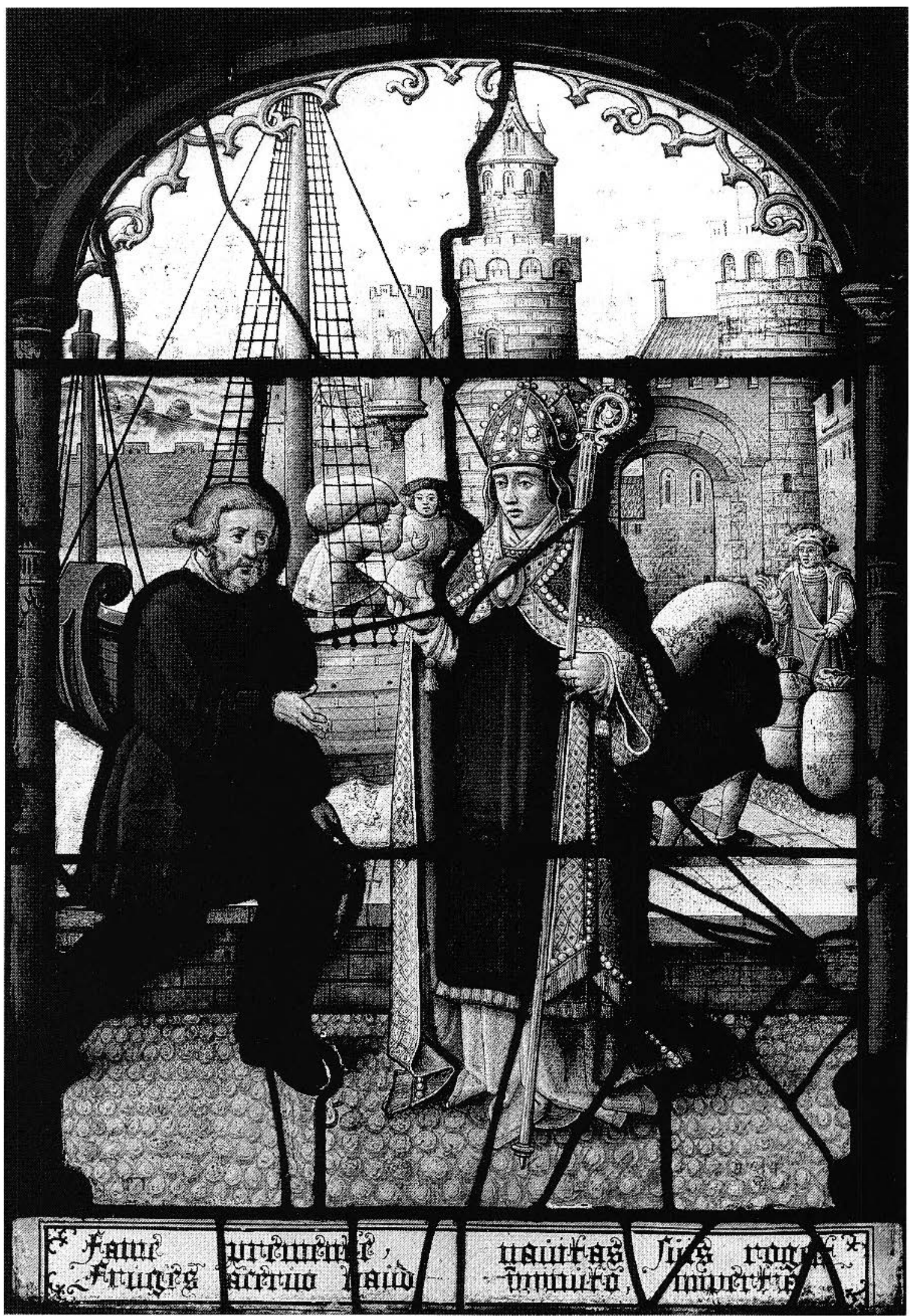


Figure 5. Saint Nicholas saving three soldiers from execution (early $16^{\text {th }}$ century), formerly from the Louvain Charterhouse. The Burrell collection, Glasgow Museum, $45 / 471$.

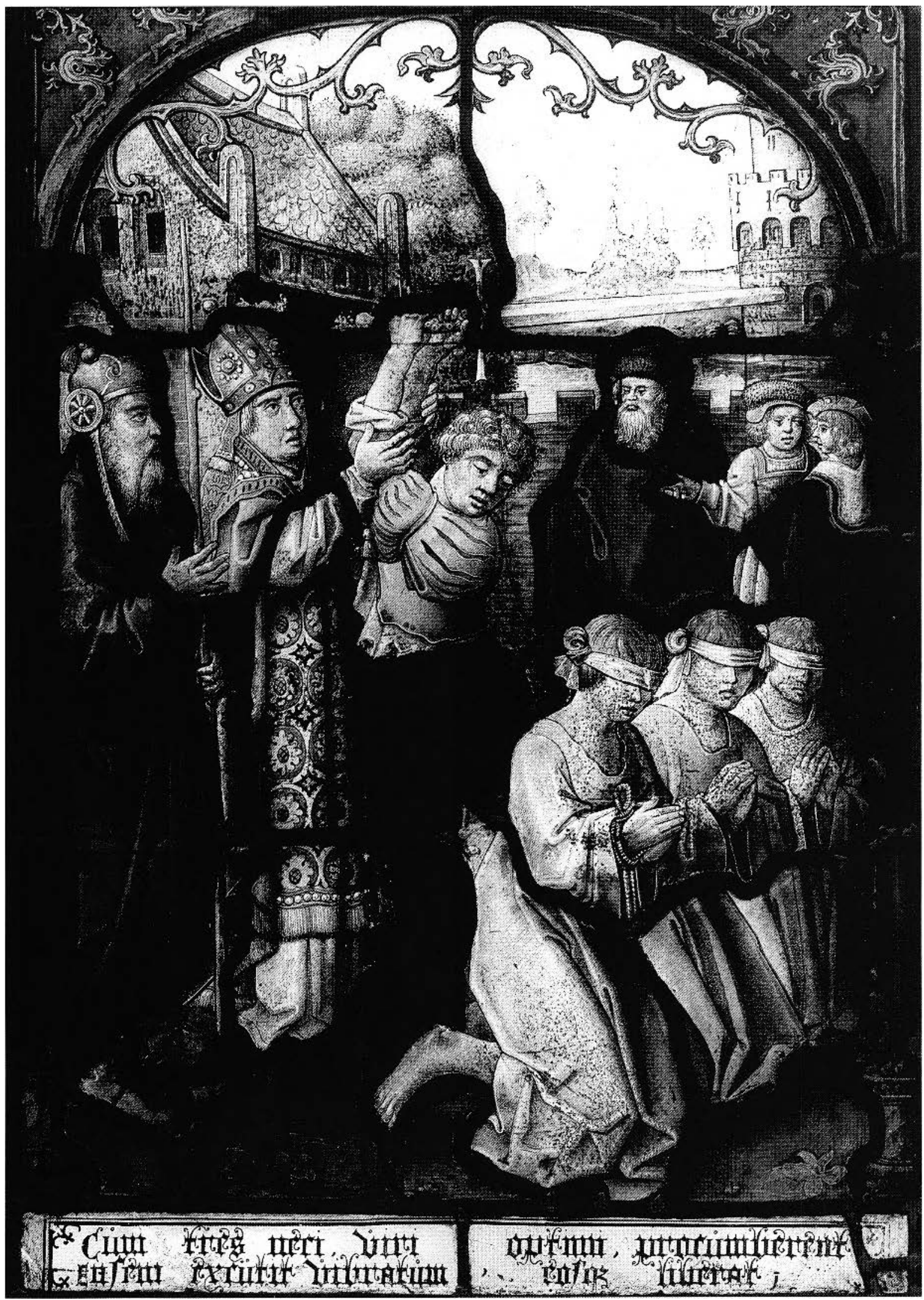


Figure 6. Saint Nicholas and the three poor maidens (early $16^{\text {th }}$ century), formerly from the Louvain Charterhouse. Present location unknown. Photocopy courtesy of the Department of World Cultures, Royal Ontario Museum, St Nicholas Series File.

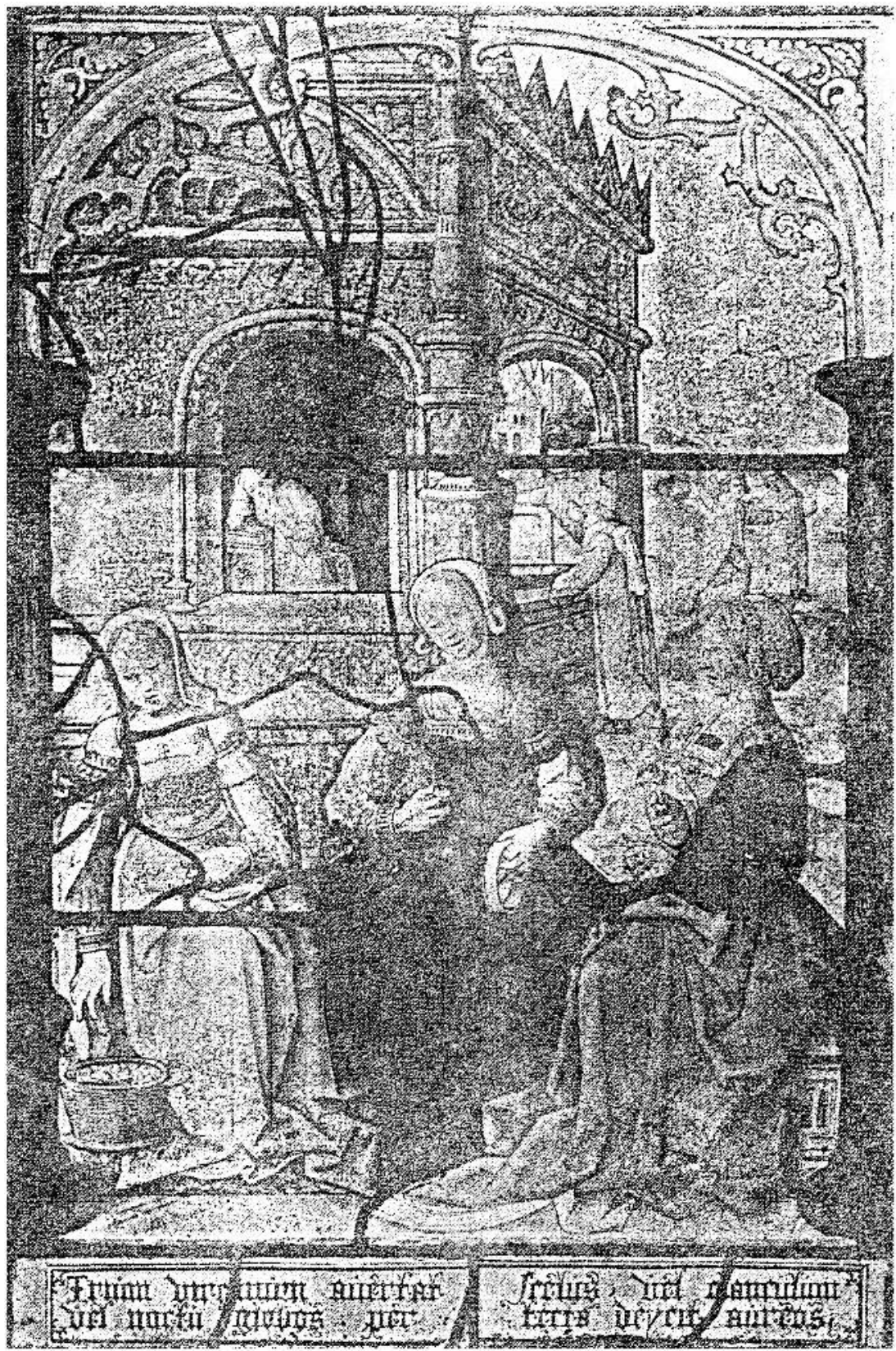

of access for poor students. Thus he is credited with the foundation of the Collège d'Arras, which still survives, and with providing funds to support sixteen students. ${ }^{11}$ The college takes its name from the city of Arras, of which Ruterius was appointed bishop in 1501 by Pope Alexander VI, on the recommendation of Philip the Fair. He was consecrated in the Cathedral of Saint-Pierre in Louvain, and celebrated his first mass in the new church of the Charterhouse, dedicated to Mary Magdalen. ${ }^{12}$ The dowager duchess Margaret of York, widow of Charles the Bold, had laid the foundation stone of the Charterhouse in 1489, and provided for the prior's cell. The construction of the cloister had started in 1492, and, on the occasion of his 1501 consecration, Ruterius also provided for the construction of a cell, which was completed in 1507, and the glazing of four bays in the cloister. ${ }^{13}$ The cloister was not completed until 1525, and its program of stained glass has been generally assigned to the years $1525-1530 .{ }^{14}$ This program was extensive. Indeed Elizabeth Pastan has recently demonstrated that the number of panels now attributed to the Louvain Charterhouse has developed into an awkward accumulation about which "it is perhaps wisest to maintain some scepticism." 15 But the St Nicholas cycle represents an independent program, quite separate from the rest of the cloister, and this must be kept in mind when considering their date. It was probably produced by one of the many glass workshops active in the region, ${ }^{16}$ although even within this iconographically consistent set of panels one can recognize at least three different hands. ${ }^{17}$

While it is a pity that the ROM panel has been shorn of whatever words once accompanied it, we are fortunate that some information about them has survived. Apparently the glass

apostolique," and he would later be named a prebendary canon in a number of locations, evidently as a reward for his distinguished services. But in 1487, when he was appointed provost of the chapter of Louvain cathedral and became ipso facto chancellor of its university, his interests turned in a new direction. Although he delegated most of the day-to-day management to his friend Adrian Florenszoon, the future Pope Adrian VI, Ruterius became closely involved with the university and appears to have been particularly concerned with the provision was inscribed with a lengthy epitaph, copied in 1613 by the chronicler Sweertius: "Stop your progress, whoever you are who arrived here, come see and read, if you want to know who I was, I Ruterus Nicolaus, mystical hero ..."; and it went on to enumerate the important facts of his life, concluding in a sentence referring to this final scene: "O divine Christ ... I, Nicolaus, humbly kneeling before you, pray that You may have my spirit soon ascend to heaven." 18 Thus Ruterius, meditating on the death of the saint as well as on his own, presents an example of 
Figure 7. Illuminated page from a breviary, attributed to a follower of the Master of Mary of Bergundy (before 1501). Louvain, Bibliothéque de la Faculté de Théologie, cod. 8, fol. 13 recto.

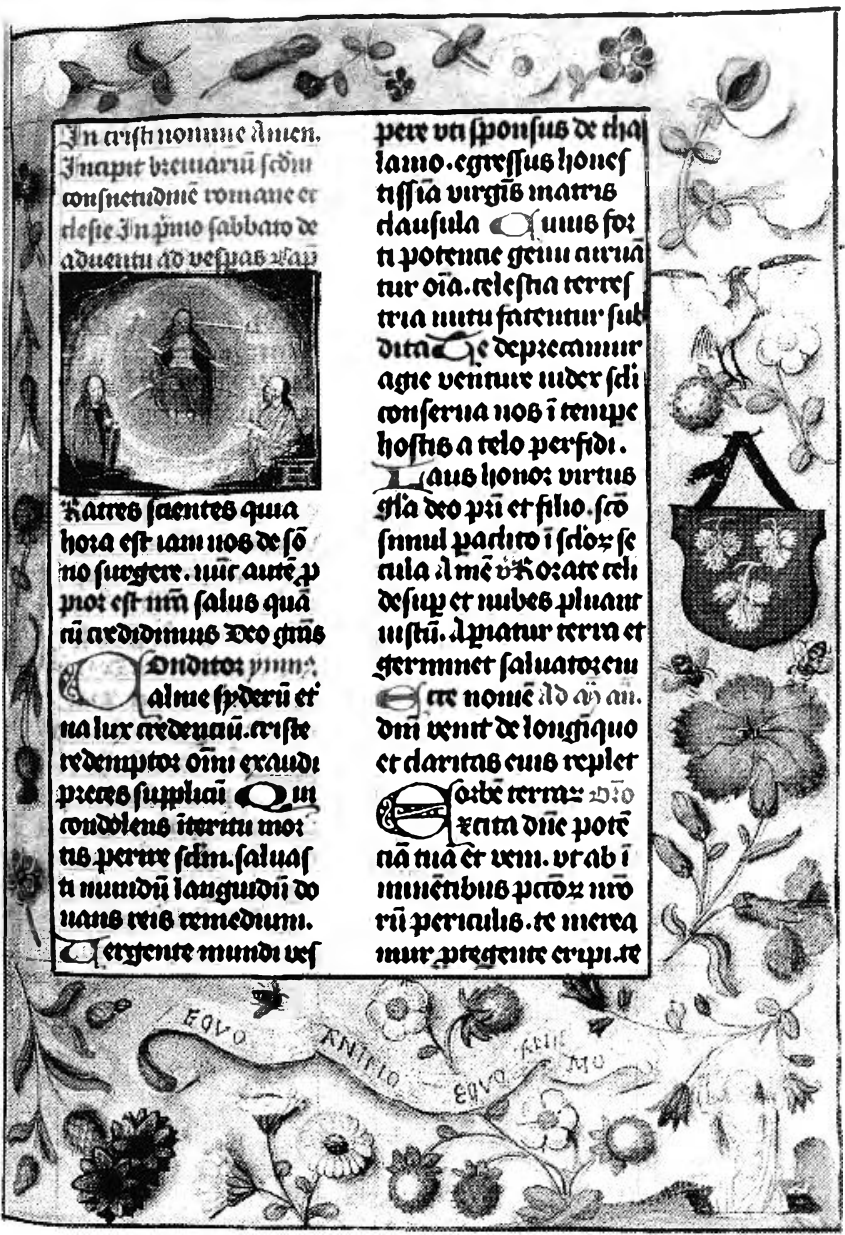

Figure 8. Coat of arms of Nicolas Ruterius, Bishop of Arras (ca. 1525), formerly from the Louvain Charterhouse. Victoria and Albert Museum, London, 2633-1855.

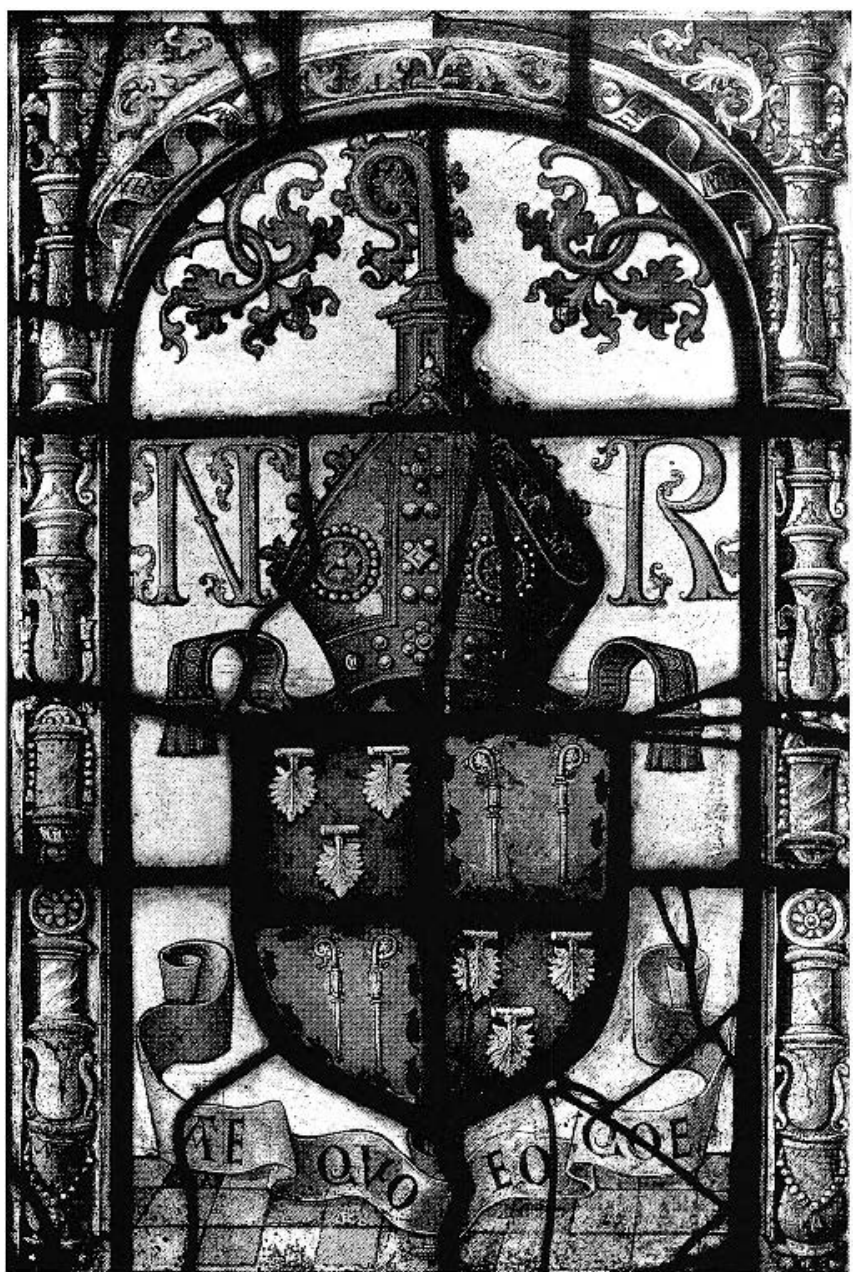

the devotio moderna, the individual piety which was so prevalent in the late Middle Ages, especially at the court of Margaret of York, and is illustrated in many Flemish paintings and manuscript illuminations of the late fifteenth century. ${ }^{19}$ His fervent devotion, and his close identification with his patron saint, may suggest that the whole series can be seen not only as a narration of the vita of St Nicholas, but also as a sequence of iconic representations of Ruterius's own life. The miracle of the grain may evoke his actions as an administrator; the scene with the military officers could signify his legal responsibilities; the dowry for the three maidens would reflect his generosity, especially towards the poor; and the saint's consecration as Bishop of Myra could be interpreted as alluding to Ruterius's own consecration as a bishop. Significantly in this context, it is known that, on that occasion, he gave to the cathedral of Arras a statue of the Virgin, in front of which two candles were to burn night and day, exactly as pictured in the background of the scene in this window. ${ }^{20}$

As for the other praying figure at the foot of the bed, I propose that he may represent Duke Philip the Fair - who would dic in 1506, the year before the completion of the cellto whom Ruterius had been so devoted and who had promoted his nomination for the episcopal see of Arras. ${ }^{21}$ Indeed Nicolas Ruterius's long career had been almost entirely based at the Burgundian court, mostly at Malines, where Margaret of York and Mary of Burgundy usually resided, and it is no wonder that, apart from his official duties, he also came to participate in the rich intellectual and artistic life of that court. Documents show that in his will he bequeathed some works of art, either in Arras or in Louvain, including a Lamentation by a follower of Rogier van der Weyden, which is now at the Mauritshuis in the Hague. ${ }^{22} \mathrm{He}$ also appears to have acquired a taste for illuminated manuscripts, an art form of considerable importance at the court of Burgundy.

The first documented evidence of such an interest is an archival note concerning the gift of a breviary to Margaret of York, in 1477, by the widow of the Chancellor of Burgundy, Guillaume Hugonet, shortly after the latter's execution in Ghent 
Figure 9. Johannes Brando, Chronodromon, vol. I, fol. I recto. Illuminated page from a manuscript attributed to the Master of the Older Prayerbook of Maximilian, ca. 1480-1485. Copyright Bibliothéque Royale de Belgique, Bruxelles, MS II.II69.

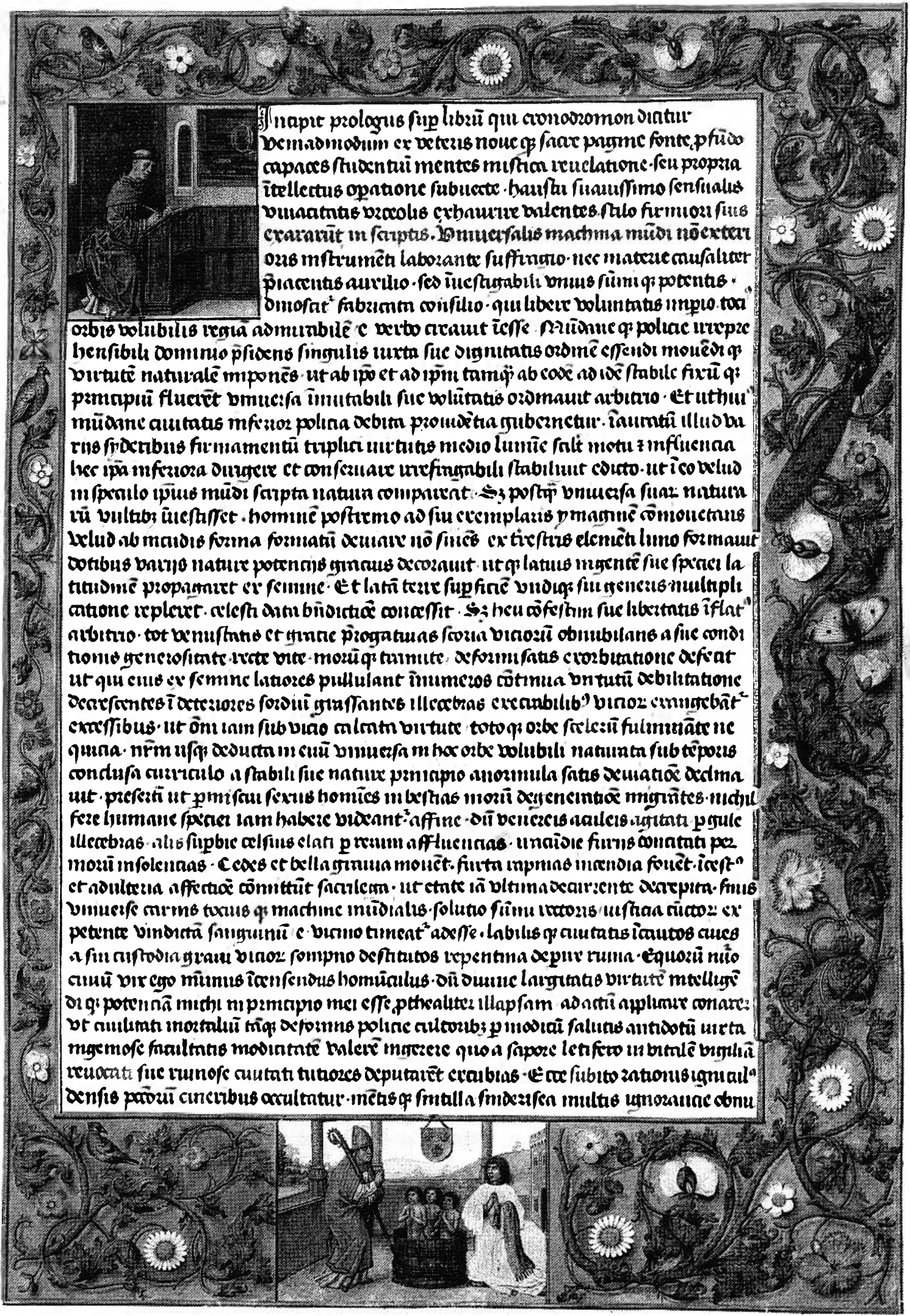


Figure 10. Chronodromon, vol. II, fol. I recto (detail).

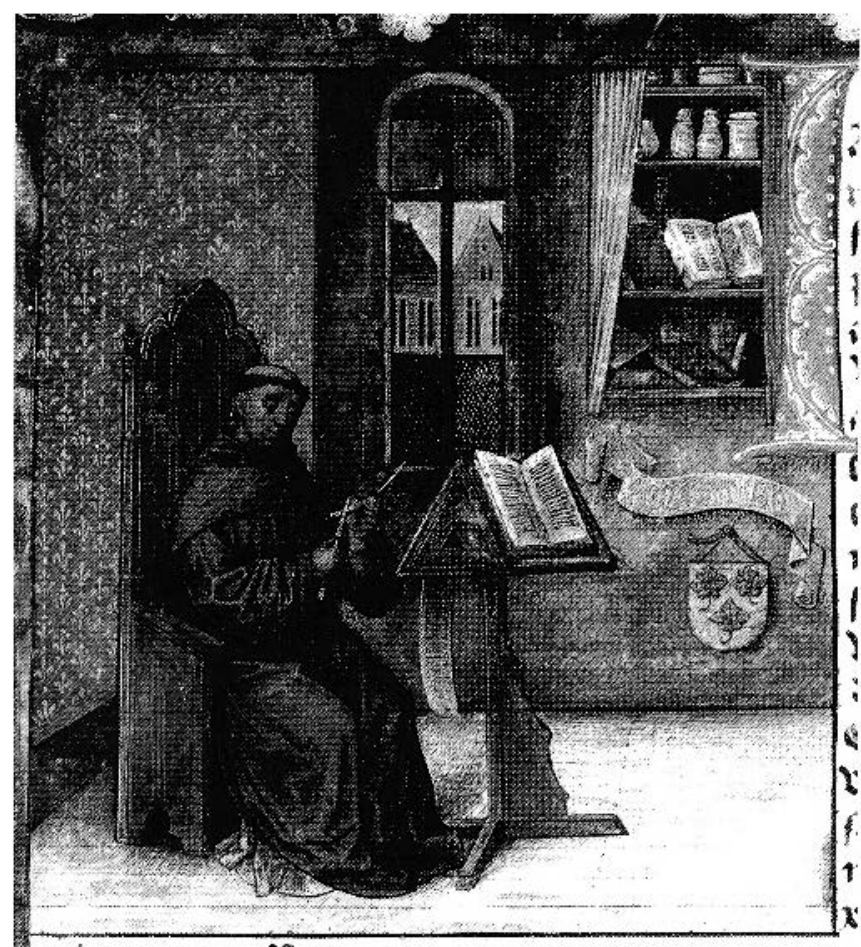

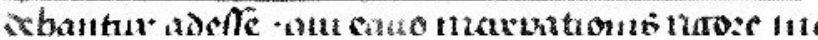

Figure II. Chronodromon, vol. I, fol. I verso (detail).

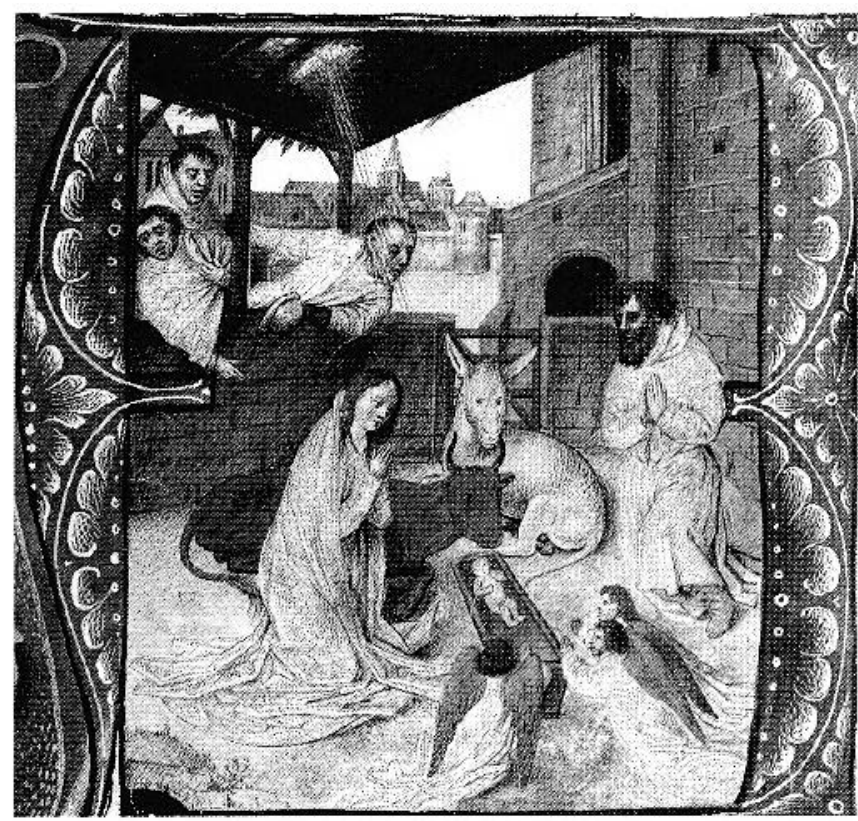

by the town's people, reacting against unpopular taxation. This little breviary "moult bel" had been given to the chancellor by "maistre Nicolas de Ruter." Its present location is unknown. ${ }^{23}$

Another important source of evidence is provided by Ruterius's gifts of manuscripts from his own library to the
Figure 12. Nativity. Illuminated page from the Hastings Hours, Maximilian Master (before 1483). By permission of the British Library, London, Add. MS 54782 , fol. 106 verso.

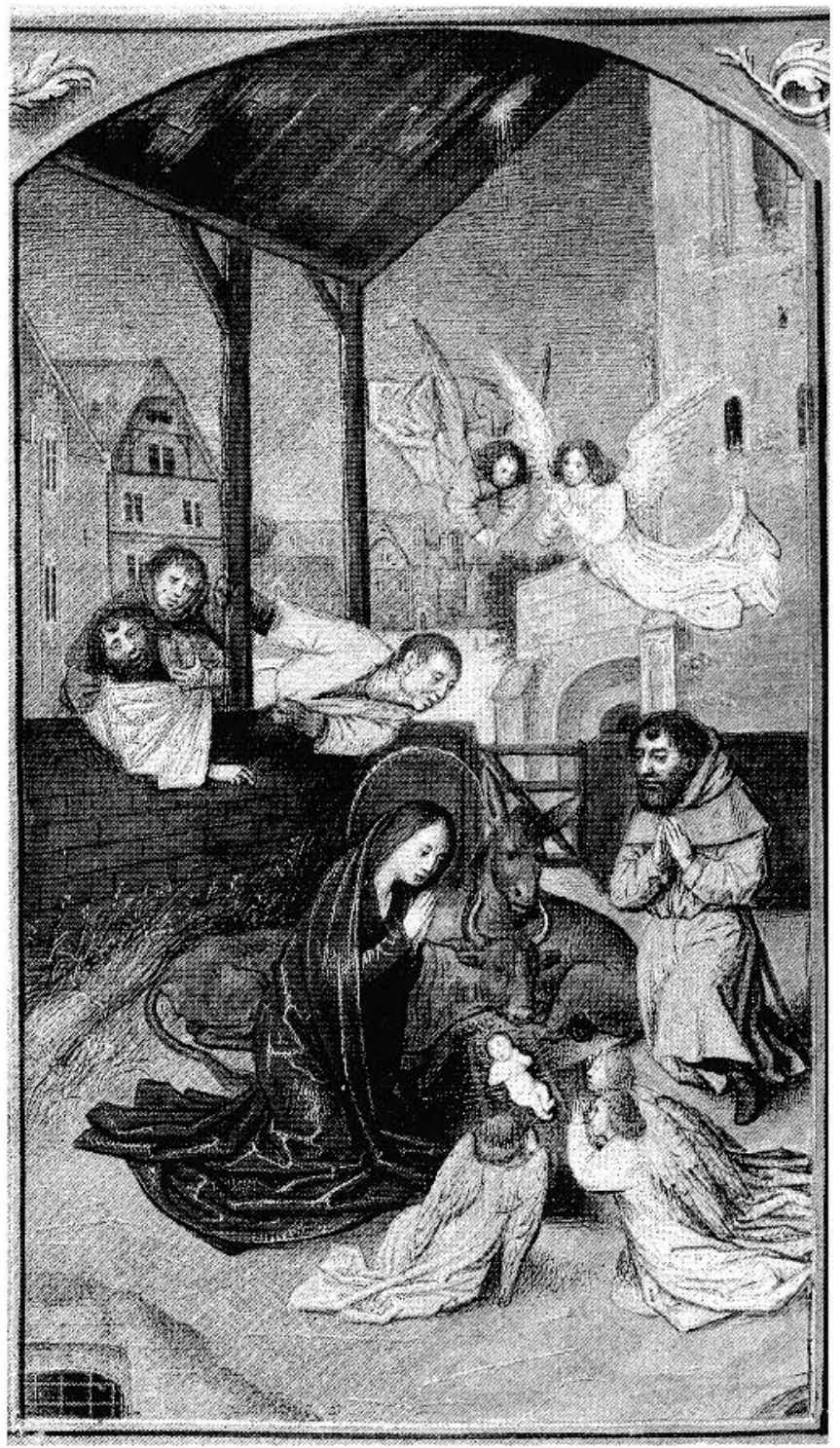

Collège d'Arras in Louvain. The most important of these is the so-called Anjou Bible, dating from the second quarter of the fourteenth century, which had once belonged to the Duke of Berry. There was also a copy of the Judaica antiquitates, by Flavius Josephus, dating from the third quarter of the fifteenth century, and a breviary which Ruterius had apparently commissioned, since it contains a depiction of his coat of arms - azure, three vine leaves gold, 2 and 1 - and his motto "aequo animo" in the margins (fig. 7). Today these are housed in the library of the Faculty of Theology at the University of Louvain. ${ }^{24}$ The Flavius Josephus is not illuminated, but denotes its owner's interest in texts on history. The breviary which he commissioned may be attributed to a follower of the Master of Mary of 
Figure 13. Chronodromon, vol. I, fol.I recto (detail).

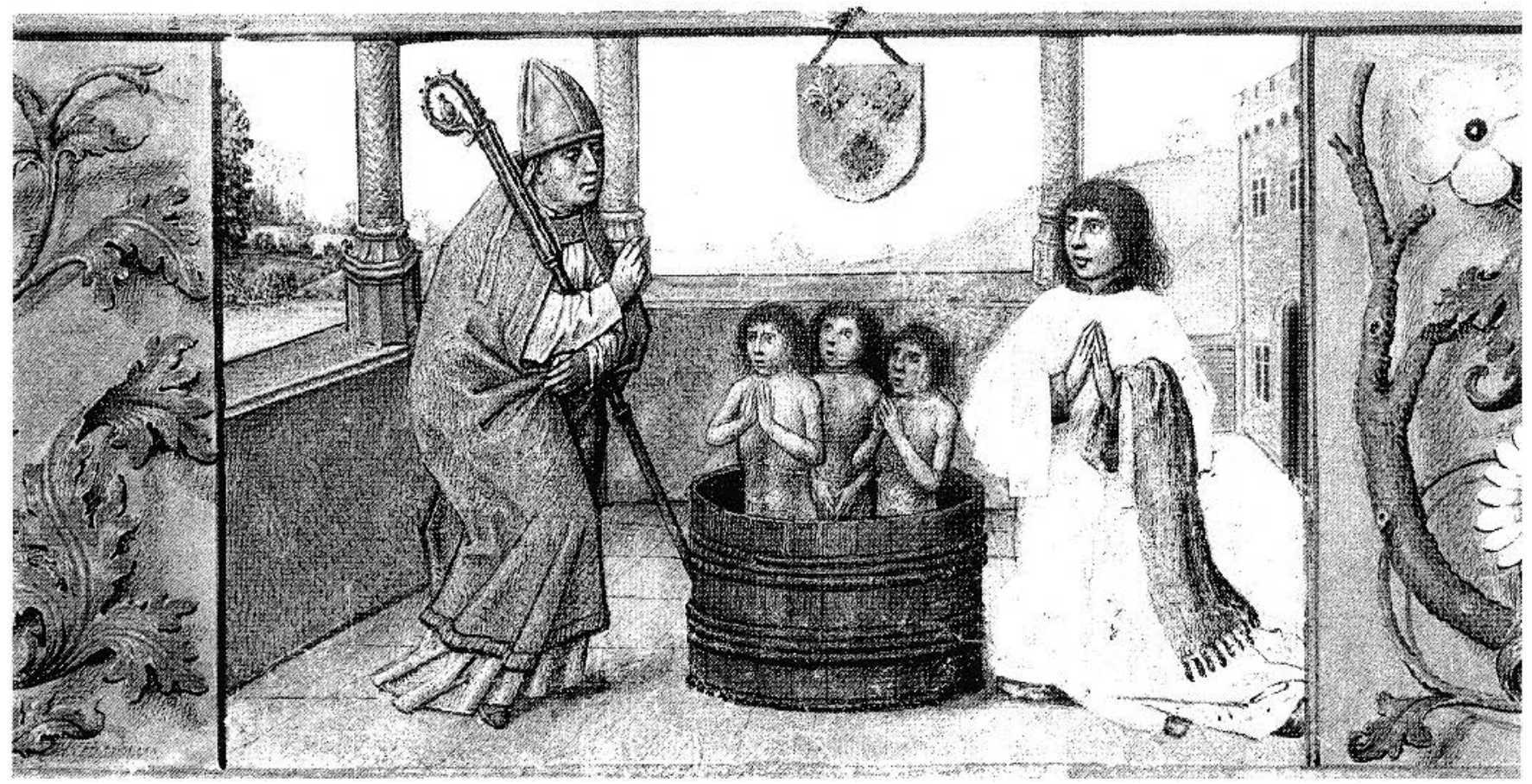

Burgundy. It must be dated before 1501, as the coat of arms predates his appointment as Bishop of Arras. This is also the case on the prayer stool in the ROM stained glass panel, while the panel in the Victoria and Albert Museum (fig. 8) shows the complete episcopal coat of arms: quartered, 1 and 4 Ruterius, 2 and 3 Arras. ${ }^{25}$

Another manuscript from the library of Ruterius, and one not included in Maes's discussion, is today in the Albertina, the Royal Library in Brussels. The text is a work of Johannes Brando, a Cistercian from Bruges, who undertook about 1414 to chronicle the history of the Low Countries, entitling it Chronodromon, or "Chronodromus seu cursus temporum." 26 It is not difficult to understand the interest that Ruterius might have had in such a subject, and he evidently commissioned his own copy, probably between 1480 and 1485 . Although the manuscript has previously been attributed to the Master of Mary of Burgundy, it is now generally ascribed to the Master of the Older Prayerbook of Maximilian, who is tentatively identified with Alexander Bening. ${ }^{27}$ It comprises three enormous volumes (about $490 \times 345 \mathrm{~mm}$ ). Only the first page of each is decorated: recto (fig. 9) and verso for the first tome, and recto only for the two others. The Ruterius coat of arms appears either in the miniatures (fig. 10) or in the margins. On each of the first pages we see the author at work, and on the verso of folio 1 in the first volume we have a depiction of the Nativity (fig. 11), which is almost identical to the one in the Hastings Hours (fig. $12)^{28}$ and can also be compared for its delicate colouring to the
Coronation of the Virgin in the Mayer van den Bergh Breviary. ${ }^{29}$ The reference to Hugo van der Goes's Portinari Altarpiece (Uffizi Gallery, Florence) is striking, and reminds us that Alexander Bening had been introduced to the Guild of St Luke in Ghent by van der Goes, to whom he was related by marriage.

The miniature that may suggest a connection to the $\mathrm{St}$ Nicholas cycle of stained glass windows may be found in the lower margin of the first folio (fig. 13). Here the patron, Nicolas Ruterius, is shown in prayer in front of his patron saint, $\mathrm{St}$ Nicholas, who, in another frequently-illustrated episode from his vita, has just saved the three boys from the butcher's shop. The facial expressions and the treatment of hair are very close to those of the figures in the ROM stained glass panel (fig. 14), even if the figure in the Chronodromon miniature appears to be younger. It may have been the case that the cartoons for the window were produced by the same workshop as the manuscript. The dating is slightly problematic, but there are many documented instances of the transmission of models through generations of artists working in the same circle. ${ }^{30}$ The ROM window must have been executed about 1500 . The coat of arms on the prayer stool and the red epomis ${ }^{31}$ that Ruterius is wearing suggest a date before his consecration as Bishop of Arras in 1501. This might also explain the fact that its framing differs slightly from the others, which are likely to have been produced later, especially the Victoria and Albert Museum panel with the episcopal coat of arms. ${ }^{32}$

In a broader sense, comparisons to work in other media 
Figure 14. Death of Saint Nicholas (detail), ca. 1501, Lormerly from the Louvain Charterhouse. Royal Ontario Museum, Toronto, 958.119.1.

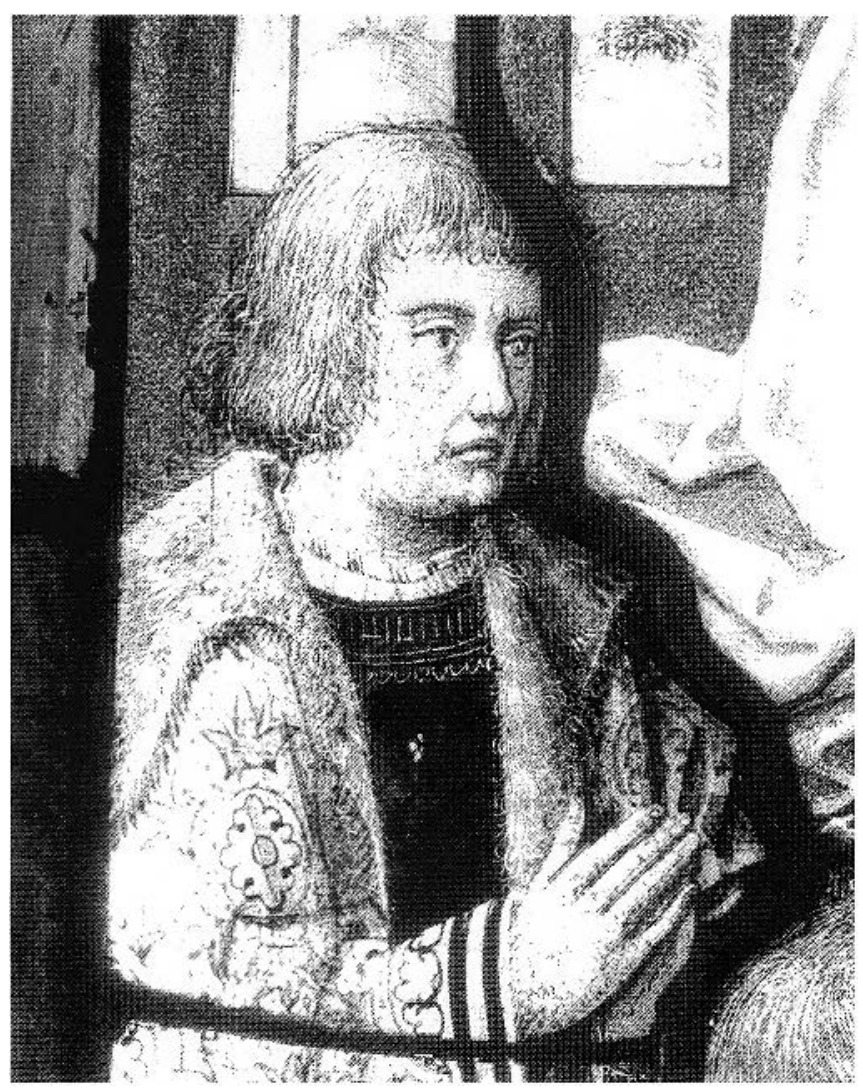

might represent a profitable line for future research on late medieval stained glass. In addition to manuscripts, another potential source of models may have been prints, and Vanden Bemden and Kerr have suggested the possible role of the Biblia Pauperum and Speculum Humanae Salvationis in this process. ${ }^{33}$ At least three stained glass panels in Prittlewell (Essex) can be linked to prints by or after Jacob Cornelis van Oostsanen, especially the Temptation by the Devil from the Passio Domini of 1523. ${ }^{34}$ And one final source of possible comparanda is the architectural décor that frames the scenes, as Papanicolau has elegantly demonstrated. ${ }^{35}$ The decorated arches framing the $\mathrm{St}$ Nicholas series and others may permit a grouping of similar pieces, as for instance two donor panels now in American collections. ${ }^{36}$

Much work on this material remains to be done, and it is to be hoped that subsequent scholarship will resolve some of these unanswered questions. Until that time, however, the ROM panel provides an eloquent testimony to what Johan Huizinga called the "Autumn of the Middle Ages," 37 when a learned cleric of indefinite origin could rise to prominence in the government, the court, and the Church, and bequeath a legacy of art and knowledge to a university college that remains active and keeps alive the memory of its founder.
Acknowledgement

I wish to acknowledge the generous support of John Osborne in editing this note.

Notes

1 Toronto, Royal Ontario Museum, 958.119.1. The panel was purchased in 1958 from Raphael Stora, a New York dealer, who succeeded Grosvenor Thomas's son Roy during World War II. See H. Hickl-Szabo, "Seven stained glass panels," Rotunda 1, no. 1 (Winter 1968), 24-31. I wish to acknowledge the kind collaboration of $\mathrm{Mr}$ Corey Keeble at the ROM.

2 The coat of arms is also found on another panel in the Victoria and Albert Museum (2633.1855), and on a seal: see Edward De Maesschalck, "Het Atrechtcollege voor 1600. Een verhaal over bisschopen en hertogen, dekens en rentmeesters," Atrechtcollege 1508-1992 (Louvain, 1992), fig. 15. The second London panel (fig. 8) is to be dated slightly later than the St Nicholas series.

3 Paul V. Maes, "Laatgotisch brandglas in Brabant," in Aspekten van de laatgotick in Brabant, exh. cat. (Louvain, 1971), 570-91; idem, "Nicolaas Ruterius en de brandglassuite met de gescheidenis van Sint-Nicolaas," Arca Lovaniensis 2 (1973), 181-207; and idem, "Leuvens Brandglas," Arca Lovaniensis 13 (Louvain, 1987). For the history of the Louvain Charterhouse, see Edmond Reusens, "Chronique de la Chartreuse de Louvain, depuis sa fondation en 1489, jusqu'à l'année 1525," Analectes pour servir à l'histoire ecclésiastique de Belgique 14 (1877), $258 \mathrm{ff}$. It is now generally accepted that the panels form a series: see Jessie McNab, Flemish Renaissance Stained Glass (New York, 1982), n.p.; Richard Marks, "Recent discoveries in medieval art," Scottish Art Review 16/1 (May 1984), 13-20; Yvette Vanden Bemden and Jill Kerr, "A group of 16th century panels from the Low Countries now in British Churches," The Journal of Stained Glass 18 (1983-84), 32-39; Hilary Wayment, King's College Chapel, Cambridge. The Side-Chapel Glass (Cambridge, 1988), 55-66; and idem, "The Master of the Mass of Saint Gregory Roundel. A Dutch Glass-painter in Brabant in the 1520s," Oud Holland 103 (1989), 61-96.

4 London, Victoria and Albert Museum, 213.1908. For the vita of St Nicholas, sce Jacobus de Voragine, The Golden Legend: readings on the saints, trans. William Granger Ryan, 2 vols (Princeton, 1993), I, 21-27.

5 New York, Metropolitan Museum, 17.120.17 and 17.120.13. Madeline Caviness et al., Stained Glass Before 1700 in American Collections: Corpus Vitrearum Check-List, Studies in the History of Art 15 (Washington, 1985), 141.

6 Glasgow, Burrell Collection, 45/471; Richard Marks, "Recent discoveries," 19-20.

7 J. De Cuyper, "Nikolaas de Ruyter," De Leiegouw 20 (June 1978), n.p.; De Maesschalck, "Het Atrechtcollege"; Erasmus en Leuven, exh. cat., Louvain, Stedelijk Museum (Louvain, 1969), passim; Maes, "Nicolaas Rutcrius"; Reusens, "Chronique."

8 Letters of 17 November 1503 and February 1504: see Percy Staf- 
ford Allen, ed., Opus epistolarum Desiderii Erasmi Roterdami (Oxford, 1906-58), 391, no. 177; and 396, no. 179.

9 As cired by Allen, ed., Opus epistolarum, 390, no. 177 (introd.); and Erasmus en Leuven, 181. Ruterius is pictured with the other clerks at the opening session of the Parliament in Malines on 3 January 1474: see De Maesschalck, "Het Atrechtcollege," 8.

10 It is in this capacity that Ruterius entrusted Erasmus with the welcoming address to Philip the Fair on the occasion of the duke's 1504 entrée into Brussels, following a lengthy stay in Spain: see Allen, ed., Opus epistolarum, 395-96, no. 179; and Erasmus en Leuven, 183-84, no. 159.

11 De Maesschalck, "Het Atrechtcollege"; and Erasmus en Leuven, 87-89, no. 65.

12 Maes, "Nicolaas Ruterius," 196-97.

13 Maes, "Nicolaas Ruterius," 196-97, and notes 19-20. The Latin text mentions four windows. From a print after a drawing of the late eighteenth century, the bays appear to have had two lancets each, and there are two bays facing each cell: see McNab, Flemish Renaissance Stained Glass. An inscription carved in the wall in golden letters dedicated the cell to Mary Magdalen: see Reusens, "Chronique," 258.

14 Maes, "Nicolaas Ruterius," 194; Vanden Bemden and Kerr, "A group of 16th century panels," 32-39; Wayment, King's College Chapel, 55-66; and idem, "The Master of the Mass of Saint Gregory roundel," 61-96.

15 Elizabeth Pastan, "Saint Catherine seized for Martyrdom," in V. Raguin, H. Zakin, and E. Pastan, Stained Glass before 1700 in the Collections of the Midwest States, Corpus Vitrearum U.S.A., part VIII (London and Turnhout, 2001), I, 131-36.

16 Maes, Leuvens Brandglas, 40-41; and J. Helbig, Les Vitraux de la première moitié du XVle siècle conservés en Belgique. Province d'Anvers et Flandres, Corpus Vitrearum II (Brussels, 1968), 12. Heendrik van Diependaal (or Diependaele) worked for the church and the cloisters of the Louvain Charterhouse probably from the beginning of the project. He died in 1509 , but his son Jan continued his workshop. One interesting document concerning van Diependaal suggests that if the work was not completed on schedule the clerics might take back the cartoons and engage a different glass-maker.

17 Conversation with Michael Archer.

18 Reusens, "Chronique," 258; and Maes, "Nicolaas Ruterius," 197:

Siste gradum, quicumque iter hac facis, advena, cerne

Et lege, si cupias noscere quantus eram,

Ille ego Ruterus Nicolaus mysticus heros...

O pie Christe Dcus, ...

... Pronus humi stratus Nicolaus flagito dona;

Spiritus ascendat protinus astra meus. (my translation)

19 On the devotio moderna, see Craig Harbison, "Visions and meditations in early Flemish paintings," Simiolus 15 (1985), 87-118; Sixten Ringbom, "Devorional images and imaginative devotions: notes on the place of art in late medieval piety," Gazette des BeauxArts series 6, 73 (1969), 159-70; and Ilya M. Veldman, "Characteristics of Iconography in the Lowlands during the period of
Humanism and the Reformation: 1480 to 1560," in Timothy Husband, ed., The Luminous Image. Painted Glass Roundels in the Lowlands, 1480-1560, exh. cat., New York, The Metropolitan Museum of Art (New York, 1995), 15-31. For Margaret of York, see Christine Weightman, Margaret of York, Duchess of Burgundy, 1446-1503 (Gloucester and New York, 1989); and Thomas Kren ed., Margaret of York, Simon Marmion and "The Visions of Tondal" (Malibu, 1992), passim.

20 Maes, "Nicolaas Ruterius," 192 and n. 9.

21 One other possibility is Guillaume de Croy, one of the four executors named in Ruterius's will. The Louvain Charterhouse had been dedicated to Mary Magdalen in honour of his wife, MarieMadeleine de Hamal.

22 De Maesschalck, "Het Atrechtcollege," 21; and Erasmus en Leuven, 98 , no. 72 .

23 Kren, ed., Margaret of York, 61, n. 7, 260.

24 Erasmus en Leuven, 92, no. 69; 96, no. 70; 97, no. 71.

25 Maurits Smeyers and Jan Van der Stock, eds, Flemish Illuminated Manuscripts, 1475-1550, exh. cat. (Ghent, 1996), 144, 146. See also Kren, ed., Margaret of York, 17-20.

26 Albertina, Royal Library in Brussels, MS II.1169 a/b/c/.

27 Frédéric Lyna, "Une oeuvre inconnue du Maître de Marie de Bourgogne," Scriptorium (1947), 310-13; and Smeyers and Van der Stock, Flemish Illuminated Manuscripts, 147-49.

28 Smeyers and Van der Stock, Flemish Illuminated Manuscripts, 42-43, fig. 48.

29 On fol. 75v, see Smeyers and Van der Stock, Flemish Illuminated Manuscripts, 76-77.

30 The relationship between manuscripts and stained glass workshops is well illustrated by the roundel of Tobias and the Fish, ca. 150010, in the Musées Royaux d'Art et d'Histoire, Brussels. In the 1920s, this was recognized by A.E. Popham as having been painted after a drawing in the Royal Library at Windsor Castle by the socalled Master of the Story of Tobit, which he dates between 1485 and 1490; it is also illustrated in the Mayer van den Bergh Breviary, which is admitredly the work of a group of artists working in Ghent around the Benings. See Smeyers and Van der Stock, Flemish Illuminated Manuscripts, 72-73; and Husband, The Luminous Image, 64-67.

31 A sort of tippct worn by professors at Louvain University over their robe (communication of Paul Maes)

32 See above, note 2.

33 Vanden Bemden and Kerr, "A group of 16 th century panels," 37.

34 Paris, Bibliothèque Nationale, Ec.6.e.Res/Fol.

35 Linda Papanicolau, "Un autre programme de cloître du XVIe siècle des anciens Pays-Bas," in Représentations architecturales dans les vitraux (Brussels, 2002), 195-200.

36 Madeline H. Caviness et al., Stained Glass Before 1700 in American Collections: Corpus Vitrearum Check-List I, 89, and eadem, ibid., Corpus Vitrearum Check-List III, (Washington, 1989), 259.

37 Johan Huizinga, The Autumn of the Middle Ages (Chicago, 1995). 